Af Jan Erik Hansen, redaktør,

jaha@kb.dk

DOI: 10.22439/revy.v43i4.6099

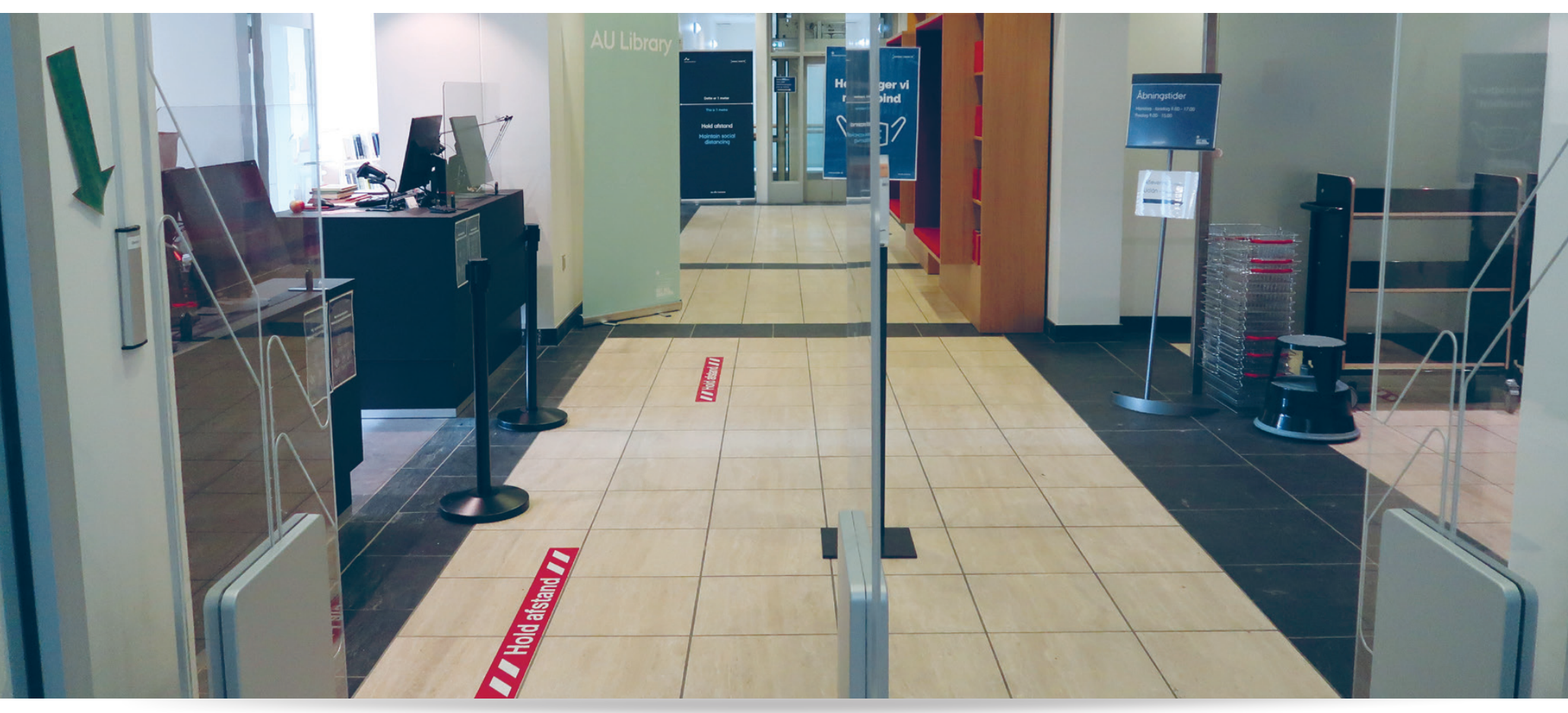

\title{
En novembersnak med den nye formand
}

"Nu handler det om at få implementeret de konkrete ting, som vi har snakket om i strategien. Især kompetencebehovet er et af de punkter hvor kollegerne derude rigtig gerne vil bruge foreningen til. At styrke fagligheden på tværs og erfaringsudveksle."

Uden for vinduet havde efteråret indtaget Campus. Løvfald og vekslende skydække. Det er blevet november og et meget mærkeligt år er så småt ved rinde ud af timeglasset. 2020 er alle måder året, der aldrig blev til noget. Det lukkede sig selv ned for omkring syv måneder siden.

Karin Englev tog imod på sit kontor bag de åbne samlinger i det, der nu er kendt som AU Library Emdrup - og som en del af den gigantiske fusion, der også hedder Det Kgl. Bibliotek. Af mange stadigvæk bedre kendt som Danmarks Pædagogiske Bibliotek.

Til daglig er hun sektionsleder på AU Library, Emdrup. For nylig har hun også sat sig i formandssædet i DFFU. Foreløbig valgt for de næste to år.

"Det har været en speciel tid. Det hele kom meget overraskende. Samtidig med at Bertil trådte tilbage, og jeg blev konstitueret formand, kom der pludselig en corona-nedlukning.", Karin Englev beskriver det seneste halve år. Det har været en omvæltning. Som en slags lammelse, der indtrådte. For foreningen og for hele bibliotekssektoren.

Alt er blevet på en anden måde, aflyste konferencer og workshops. $\mathrm{Og}$ senest en generalforsamling der blev gennemført skriftligt via mail-tilkendegivelser. $\mathrm{Og}$ endelig et fredsvalg til formandsposten.

"Omkring generalforsamlingen diskuterede vi i bestyrelsen, om en hybrid model kunne lade sig gøre.", forklarer hun, "Altså nogle kunne fysisk møde op, mens andre deltog online. Men der blev vi desværre indhentet af corona-virkeligheden. Det var i planlægningsperioden, at Aarhus blev lukket 


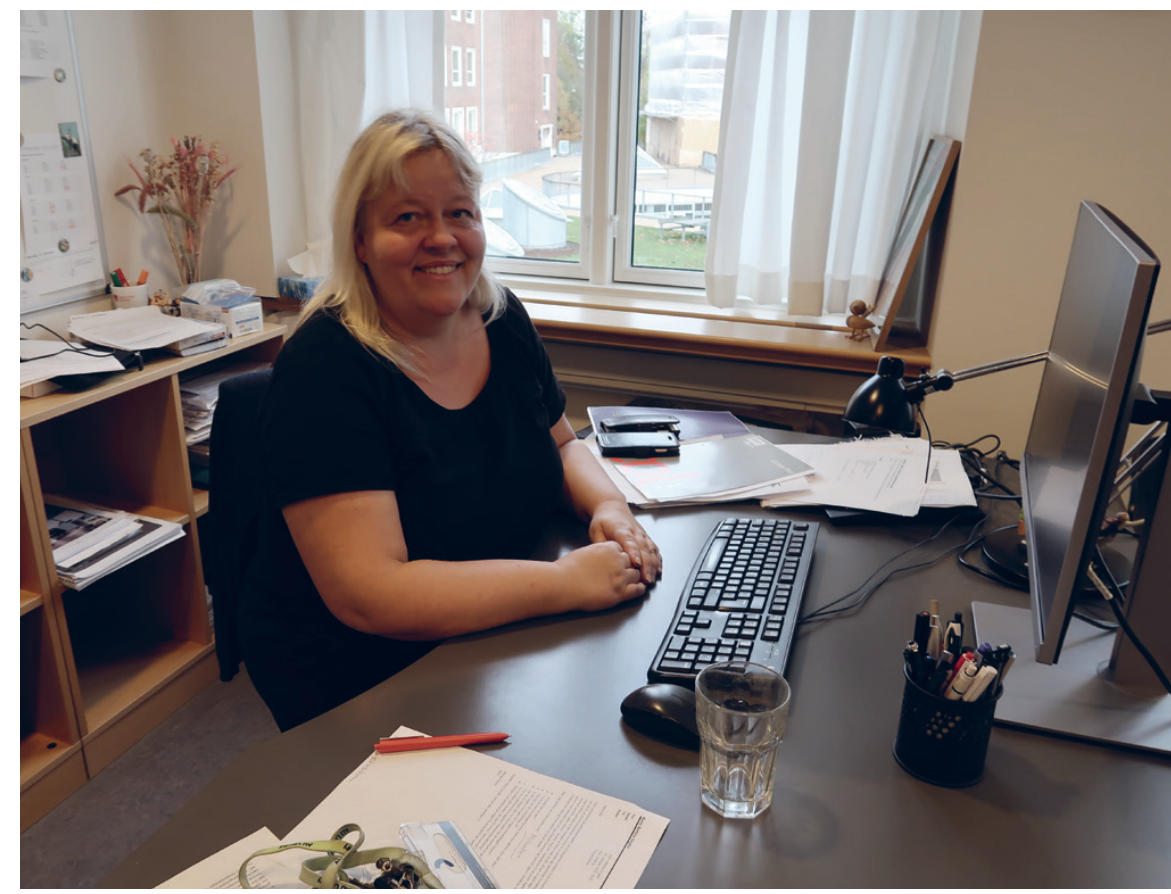

ned igen, og vi skønnede, at det ville give en skævvridning geografisk i fremmødet."

"Vi talte også om, at arrangere det som et $\mathrm{k}$ æmpe zoom-møde. Men der var en masse tekniske udfordringer, som vi ikke var helt klar på i det tidlige efterår."

"Det havde været en mulighed, at rykke generalforsamlingen., fortsætter hun, "Men vi frygtede, at det hele ville gå for meget i stå. Fordi det ville tvinge bestyrelsesmedlemmer, der allerede havde ønsket at stoppe i september, til måske at sidde et halvt år mere."

"Det var bedre, at få de formelle valg afviklet og få en ny bestyrelse på plads."

Den skriftlige generalforsamling blev gennemført i september, en ny bestyrelse trådte til og Karin Englev gik fra konstitueret til nyvalgt formand.

Kan du beskrive din egen vej inden for $i$ DFFU?

"Oprindelig begyndte jeg i FORFRA, vores forum for fjernlån, og blev efter par år spurgt om jeg ikke ville deltage i bestyrelsesarbejdet. Det lød spæn- dende, jeg ville gerne være med til at lave arrangementer for foreningen, og tænkte selvfølgelig at det skal prøves. bestyrelsen har jeg både været menigt medlem, senere kasserer i en årrække og senest som næstformand."

"Dengang blev jeg prikket af min chef, fordi der manglede nye folk til bestyrelsen. $\mathrm{Og}$ som sagt var det jo oplagt, fordi jeg i forvejen var aktiv i FORFRA. Jeg stillede op til valget og kom ind."

\section{Fra næstformand til formand}

Og du var ikke i tvivl omkring at overtage formandsposten?

"Nej. For mig er det en spændende udvikling at være med til at sikre, at der stadig er et behov for en forening som DFFU. At sikre at der stadig er et fælles fagligt rum for professionshøjskoler og andre universitetsbiblioteker end lige os der er ansatte i Det Kgl. Bibliotek.", siger Englev.

"Samtidig har jeg været meget engageret i vores store strategirapport, som foreningen fik lavet i samarbejde med Tænketanken. Det er vigtigt, at DFFU har fået sig en strategi fremadrettet. Vi er nødt til at gøre os klart, hvad er det egentlig vi er til for, og hvor er vi på vej hen."
"Dengang jeg kom ind i Sektoren for 20 år siden, var der masser af selvstændige biblioteker. Det er for så vidt stadig. Men fusioner og sammenlægninger har også ændret landskabet meget. Nu er mange af os ansat det samme sted (Det Kgl. Bibliotek, red). Det synes jeg gør det endnu mere vigtigt at vi beholder et sted, hvor vi kan mødes med kollegerne udenfor. At være sammen fagligt. At sikre at vi fortsat bliver et samarbejdende biblioteksvæsen. Der mener jeg, at DFFU kan få en stor rolle."

"Nu handler det om at få implementeret de konkrete ting, som vi har snakket om i strategiplanlægningen. Især kompetencebehovet er et af de punkter, som kollegerne derude rigtig gerne vil bruge foreningen til. At styrke fagligheden på tværs og erfaringsudveksle. Det er noget vi meget gerne vil tage fat om. Ud over foraernes rigtigt gode og relevante konferencer og temadage bør vi også tage fat på, at lave noget projektsamarbejde på tværs. Jeg hører, at det er savnet. At vi kan lave projekter på tværs, som tidligere i DEFF-regi."

"Der skal vi kigge på, om det er en rolle som DFFU kan påtage sig nu, hvor DEFF ikke eksisterer længere. Det hænger i den grad sammen med strategiens punkter omkring relationer og synlighed."

\section{Visioner}

Det bringer os videre til din vision for de næste år på formandsposten. Hvor ser du gerne, at DFFU bevæger sig hen?

"DFFU skal være en aktør, der bliver tænkt på i forskellige relevante kontekster. Men vi skal også samarbejde med andre aktører inden for bibliotekssektoren. 
Men vi kan godt blive endnu bedre og mere opsøgende i forhold til nye samarbejdspartnere.", siger Karin Englev.

"Men politisk skal vi også være med til at sætte en tydeligere dagsorden, som vil give os synlighed i forhold til vores universiteter. Rent fagligt. Så det ikke bare handler om fusioner og sammenlægninger."

"Vi skal i endnu større grad også samarbejde med andre interessenter og også med folkebibliotekerne. Og for at vende tilbage til kompetencebehovet. Jeg tror, at det er vigtigt at vi finder en model hvor vi, ud over foraer og arrangementer, også kan tilbyde konkrete projekter der foregår på tværs og mellem både universitetsbiblioteker og professionshøjskoler."

"Det er klart, at det vil kræve et økonomisk fundament, og der kan vi ikke matche det som DEFF var som statsfinansieret organ. Så mange penge råder vi ikke over i foreningen."

"Men måske kunne sige som et tænkt eksempel", understreger hun, "at foreningen gav et beløb på måske 100.000 kroner til at understøtte et projekt, hvor medarbejdere på de enkelte biblioteker så fik allokeret tid og ressourcer til at deltage, og at DFFU bliver garant for kvalitet i projektet."

"Det bliver selvfølgelig svært og måske vil det kun være to projekter om året, man kan facilitere på den måde. Men det er måske bedre end ingenting. Det at der bliver sat projekter i søen, der uafhængige af et moderbibliotek, og som er tværgående vil være med til at skabe en ny synergi."

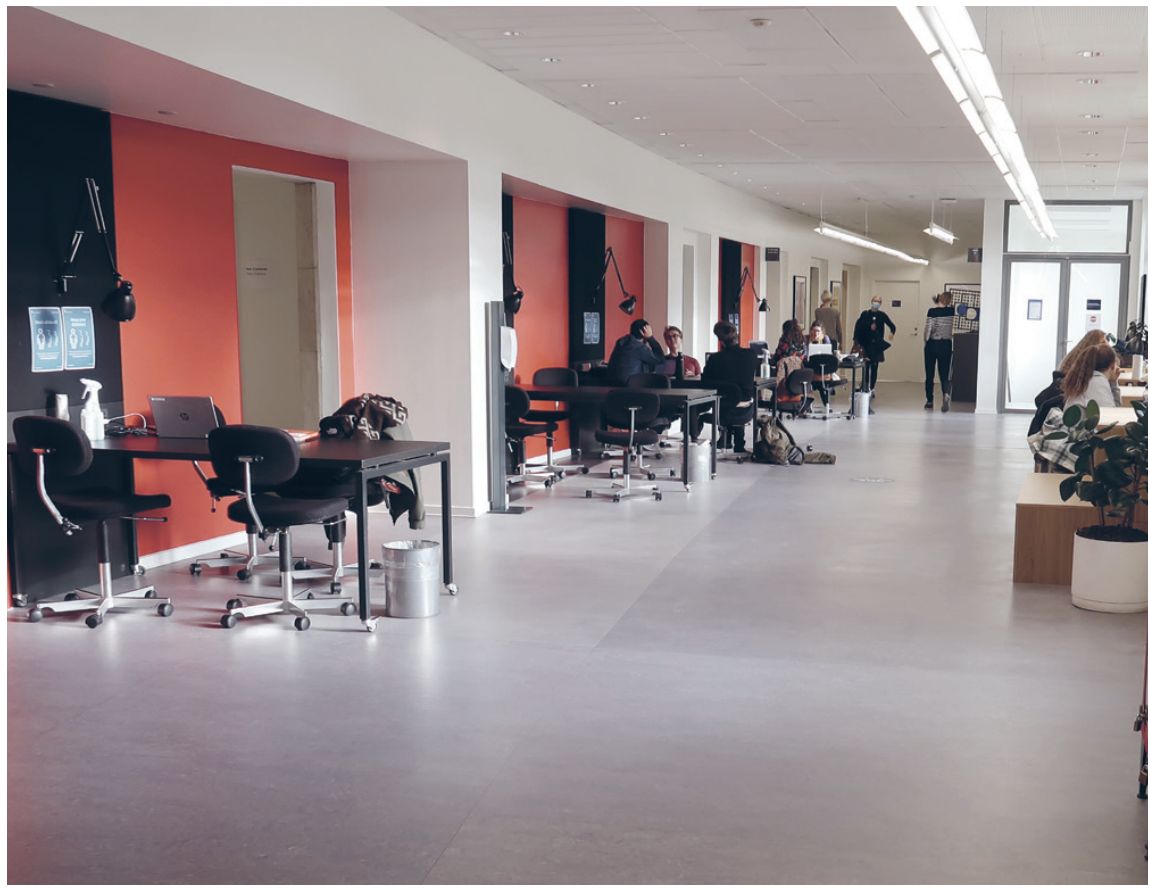

\section{Det Kgl. Bibliotek og de andre}

Kunne man ikke frygte at Det Kgl. Bibliotek $(K B)$ lukker sig mere og mere om sig selv. Alene i kraft af sin størrelse $i$ sektoren nu?

"Der tænker jeg, at KB også må være interesseret $\mathrm{i}$ at få input andre steder fra. Jeg tror, som jeg kender til KB, at man er interesseret $i$ at støtte et samarbejde ud ad til. DFFU skal så vise, at der faktisk kommer faglig kvalitet ud af projekterne. Det er klart."

"Men det er rigtigt, at der lige i øjeblikket måske er meget andet der fylder hos KB. Vi er stadig midt i en stor fusion. Der bliver det DFFUs rolle at gå ind og gøre sig mere synlige."

"I forhold til synligheden er vi i bestyrelsen meget bevidste om hvor vigtigt der er, og det har vi også gjort en del ud af de senere år, ved at være en god sammensætning af ledere, og medarbejdere."

"Det er vigtigt at have medarbejdere med også. Det skal ikke bare være en forening for ledere. Men igen tror jeg også, at bestyrelsen skal være bedre til at gøre sig mere synlige. Hvad er det egentlig vi taler om, og hvad laver vi, og hvilke muligheder har medlemmerne for at have indflydelse." Hun fortsætter,

"Der kunne vi måske også have været endnu tydeligere omkring strategien."

"Vi skal i det hele taget være bedre til at fortælle de gode historier fra DFFU og vi skal måske også overveje om foraerne skal have mere plads, for de har netop været gode til også at hverve nye medlemmer, og vi måske skal bruge vores hjemmeside på en anden måde."

"Men hele vejen rundt kræver det at nogle gør noget, og især har tiden til at gøre noget."

"Der mener jeg, at REVY har en vigtig rolle.", forklarer Englev. REVY er naturligvis ikke uenig."Jeg ved at bladet læses af bibliotekarer også på små steder ude i sektoren."

"Ligesom vores fora-arrangementer bliver meget vigtige også fremadrettet. Heldigvis oplever vi der masser af engagement, også fra de mindre biblioteker." 


\section{"Vi skal måske \\ bare tænke \\ mere bredt, \\ når vi inviterer \\ ud til vores}

arrangementer."

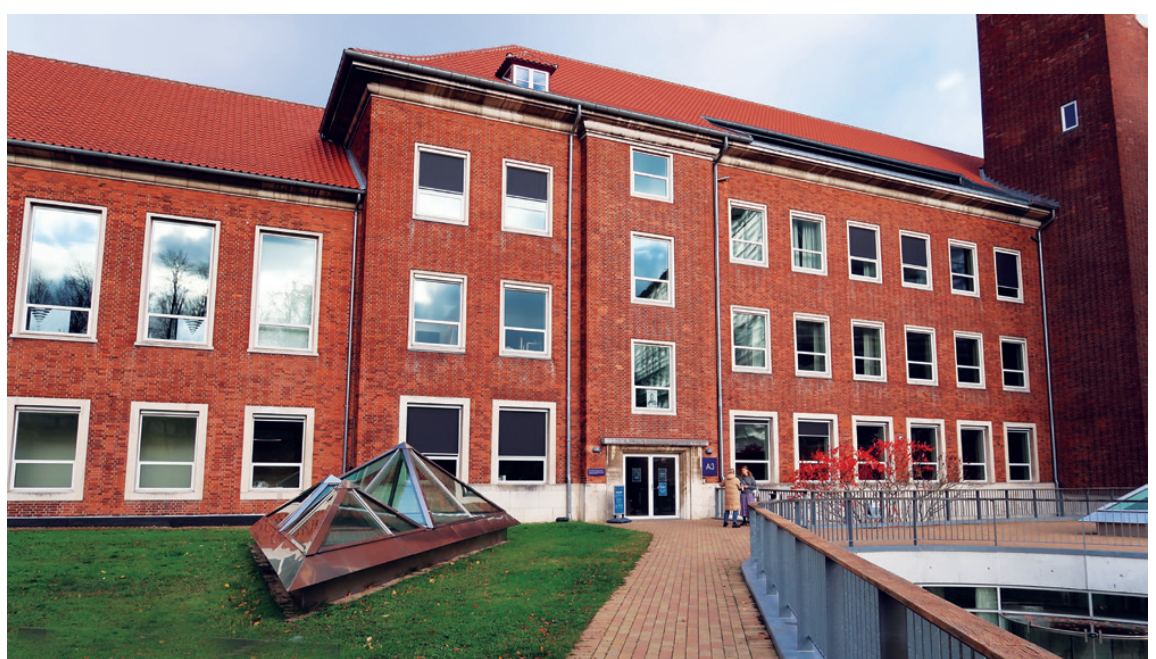

strategien. De laver også meget for folkebibliotekerne."

"Vi skal måske bare tænke mere bredt, når vi inviterer ud til vores arrangementer."

\section{Og på bagsiden af corona}

Det er svært at undgå at tale om det. Coronaen. Hvilken virkelighed ser du, at der venter os ude på den anden side for bibliotekerne?

"Vi kommer også til at arbejde meget mere hjemmefra. Det skal vi nok vænne os til. Vi kommer ikke til at møde kollegerne på samme måde fremover. Igen der er fordele og der er ulemper. Men det kommer til at betyde noget for vores møder på arbejdspladsen."

"Vi har lært at vi sagtens kan opretholde en masse service virtuelt. Men vi skal nok også være bevidste om, at den fysiske tilstedeværelse ikke kan erstattes. Nu sidder jeg selvfølgelig på et humanistisk bibliotek og der har savnet at den fysiske adgang til materialerne eller bare kontakten til en bibliotekar været markant."

"Som nævnt tidligere har vi i DFFU-bestyrelsen om den hybride model, hvor nogle møder fysisk frem til et arrangement, og andre kan vælge at deltage virtuelt hjemmefra. Det skal vi nok bare kaste os mere ud i.", siger Karin Englev og lader det være en slags slutreplik for interviewet.

Vi skal nok bare kaste os mere ud i det. Som denne eftermiddag i begyndelsen af november. Med vekslende skydække - og snart på den anden side af 2020.

"Men vi skal huske på, at vi i DFFU-regi har en bred vifte af ansatte på bibliotekerne, som også indbefatter HK, DM m.fl., og dem skal vi jo også ramme med kommende fælles arrangementer. Det tror jeg så også sagtens, at vi kan gøre. Vi har også samarbejdet rigtig meget med Tænketanken, senest om

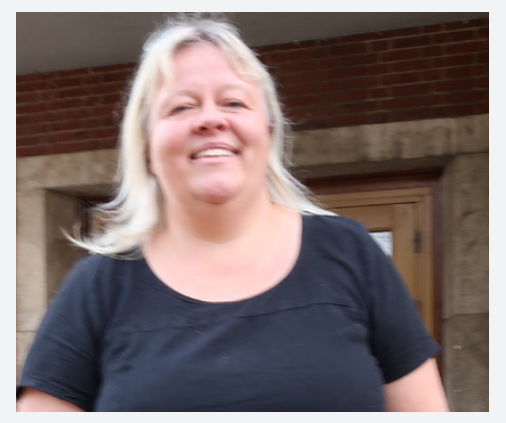

\section{Karin Englev}

- Sektionsleder Emdrup, AU Library Det kgl. Bibliotek

- Formand for Danmarks Fag-, Forsknings- og Uddannelsesbiblioteker,

- Master of Public Governance, CBS, 2016-2019

- Forskellige stillinger ved Roskilde Universitetsbibliotek bl.a. Funktionsleder, Specialkonsulent.

- LIBER Emerging Leaders Programme, 2015/16

- Bestyrelsesmedlem i DFFU, FORFRA, 2006-2013

- Kandidat i historie og kommunikation fra Roskilde Universitetsbibliotek, 2005

- Bachelor i dansk sprog og litteratur fra Roskilde Universitetsbibliotek, 1996 